\title{
A NEW SPECIES OF ANTHURIUM (ARACEAE) FROM OAXACA, MEXICO
}

\author{
Thomas B. Croat ${ }^{1,3}$ and Alejandro de Ávila Blomberg ${ }^{2}$ \\ ${ }^{1}$ Missouri Botanical Garden, P.O. Box 299, St. Louis, MO 63166-0299, USA \\ 2Jardín Etnobotánico de Oaxaca, Apdo. postal 367, colonia Centro, \\ 68000 Oaxaca, Oaxaca, México. \\ ${ }^{3}$ Author for correspondence: thomas.croat@mobot.org
}

\begin{abstract}
Anthurium coicoyanense Croat \& de Ávila is described as new from a heretofore poorly collected area in Oaxaca State in Mexico. The species is a member of an as yet unpublished section of the genus that comprises a total of thirteen Mexican species. That section will be proposed formally in an upcoming paper by Croat and Monica Carlsen from the Missouri Botanical Garden.
\end{abstract}

Key words: Anthurium, Mexico, new species, Oaxaca.

\section{RESUMEN}

Se describe a Anthurium coicoyanense Croat \& de Ávila como una especie nueva proveniente de una área pobremente explorada en el estado de Oaxaca en México. El taxon nuevo es miembro de una sección hasta ahora inédita del género que comprende trece especies mexicanas en total. Dicha sección será propuesta de manera formal en una publicación que preparan actualmente Croat y Mónica Carlsen del Jardín Botánico de Missouri.

Palabras clave: Anthurium, México, nueva especie, Oaxaca.

\section{INTRODUCTION}

The genus Anthurium was last revised for Mexico by the senior author (Croat, 1983); 219 species had been recorded for all of Central America (including Mexico, 
Middle America and Panama). At that time, Mexico had 41 known taxa, with 26 endemic species. As was then reported (Croat, loc. cit.), six species are relatively wide spread: A. andicola Liebm., A. chiapasense Standl., A. schlechtendalii Kunth, A. nizandense Matuda, A. ovandense Matuda, A. pedatoradiatum Schott, and $A$. podophyllum (Schltdl. \& Cham.) Kunth. The majority of the Mexican species are however relatively narrow endemics, mostly known from northern Oaxaca (eight taxa: A. cerropelonense Matuda, A. chamulense ssp. oaxacanum Croat, $A$. longipetiolatum Matuda, A. machetioides Matuda, A. nelsonii Croat, A. subovatum Matuda, A. umbrosum Liebm., A. yetlense Matuda); northern Chiapas (four taxa: A. berriozabalense Matuda, A. clarinervium Matuda, A. leuconeurum Lem., A. lezamai Matuda); or southeastern Chiapas (two taxa: A. cordatotriangulum Matuda, A. nakamurae Matuda).

In addition to these narrow endemic species, yet another one was published for Mexico in the revision of Anthurium section Pachyneurium (Croat, 1991), namely A. sarukhanianum Croat \& Haager, known only from the lowlands of Guerrero State. Even later another rare endemic species was described from Chiapas, Anthurium faustomirandae Pérez-Farrera \& Croat (Pérez-Farrera \& Croat, 2001). The latter species is presently deemed to be a member of section Calomystrium. Further to the south in Guatemala, a number of new species have been discovered. Moreover, many species have been found in the southern extremes of Central America, in Costa Rica and especially in Panama (Croat \& Ortiz, in prep.). Most of the species that have been discovered there pertain to the section Porphyrochitonium (Croat et al., in prep.).

The new taxon here proposed appears to be yet another narrow endemic, this one from western Oaxaca State in an area that had not been studied previously.

Anthurium coicoyanense Croat \& de Ávila, sp. nov. Type: MEXICO. Oaxaca; Sierra Sur, distrito de Juxtlahuaca, municipio de Coicoyán, Nami Ndoso Itia, SW of Coicoyán, bosque húmedo cerca de cascada, $17^{\circ} 15^{\prime} \mathrm{N}, 98^{\circ} 18^{\prime} \mathrm{W}, 2400 \mathrm{~m}, 16$ Mar., 1988, Alejandro de Ávila Blomberg 228 (holotype, MEXU; isotype, NY) (Figs. 1, 2).

Hemiepiphytic; stems to $2 \mathrm{~cm}$ diam., with short internodes; cataphylls not seen; petioles D-shaped, $45 \mathrm{~cm}$ long, $5 \mathrm{~mm}$ diam., drying gray-green, weakly glossy and densely pale short-lineate, broadly sulcate adaxially with bluntly acute, somewhat spreading margins; blades narrowly ovate-triangular-sagittate, narrowly acuminate at apex, prominently lobed at base, 44.3-49.7 cm long, 17.7-18 cm wide, 2.5-2.7 times longer than wide, about as long as petioles, broadest slightly above the petiolar 
plexus, subcoriaceous, semiglossy, somewhat bicolorous, dark green above, drying grayish green and weakly glossy above, moderately paler and grayish yellow-green below; anterior lobe $37.3-48.5 \mathrm{~cm}$ long, broadly concave to almost straight on the margin, convex toward the apex; posterior lobes 9.7-11.7 cm long, $6.2-6.7 \mathrm{~cm}$ wide, turned somewhat inward; sinus spatulate, $8 \mathrm{~cm}$ deep, $4.2 \mathrm{~cm}$ wide; midrib weakly raised, narrowly rounded and concolorous above, narrowly rounded and slightly paler below, drying somewhat acute and finely ribbed, faintly pale short-lineate below; primary lateral veins 10-13 pairs, scarcely distinguishable from the interprimary veins, arising at ca. $50^{\circ}$ angle, concolorous and weakly raised above, narrowly rounded and slightly paler below, drying more or less concolorous; tertiary veins scarcely raised; basal veins 3-4 pairs, none free to the base, $1^{\text {st }}$ pair spreading at ca. $90^{\circ}$ angle and curving abruptly upward; collective veins arising from the $1^{\text {st }}$ pair of basal veins, $1.5-2 \mathrm{~cm}$ from the margins, $2^{\text {nd }}$ and $3^{\text {rd }}$ fused $2.5-3.2 \mathrm{~cm}$, $4^{\text {th }}$ basal vein essentially marginal; posterior rib nearly straight, naked throughout most of its length; surfaces moderately smooth and unmarked on magnification. Inflorescence erect-spreading; peduncle 40-41.5 cm long, drying same color as petiole, $4 \mathrm{~mm}$ diam.; spathe lanceolate, 6-6.8 cm long, 1.5-2 cm wide, green, narrowly acuminate, erect-spreading; spadix green, cylindroid-tapered subsessile, $7.5-8.8-9 \mathrm{~cm}$ long, drying $1.1 \mathrm{~cm}$ diam. at base, $1 \mathrm{~cm}$ diam. midway, $7 \mathrm{~mm}$ diam. at $1 \mathrm{~cm}$ from tip, narrowly rounded at apex; flowers 6-7 visible per spiral, subrounded (at least on drying), 3.3-3.6 mm long, 3.4-4 $\mathrm{mm}$ wide; tepals drying yellow-brown, minutely papillate, often turned up markedly on drying; lateral tepals 2.2-2.6 mm wide, inner margin broadly rounded, outer margin bluntly 2-sided; stamens held at level of tepals, anthers $0.6 \mathrm{~mm}$ long and wide; thecae slightly divaricate; stigma broadly ellipsoid, $7 \mathrm{~mm}$ x $6 \mathrm{~mm}$. Fruit not seen.

The new species, Anthurium coicoyanense, is placed in an as yet unpublished new section centered around a group of species with thick stems, short internodes, D-shaped petioles and orange berries with a mealy endosperm. That group includes the following Mexican species: $A$. andicola Liebm., A. berriozabalense Matuda, $A$. cerrobaulense Matuda, A. chamulense Matuda, A cordato-triangulum Matuda, A. montanum Hemsl., A. nakamurae Matuda, A. nelsonii Croat, A. rionegrense Matuda, A. rzedowskii Croat, A. seleri Engl., A. subovatum Matuda, and A. titanium Standl. \& Steyermark. In the revision of Anthurium of Mexico and Middle America (Croat, 1983), these species were tentatively placed in section Belolonchium, but at the time the senior author expressed the opinion that this group that he referred to as the Anthurium andicola complex might ultimately prove to be a new section (Croat, 1983, p. 214). Indeed, a recent molecular study by Monica Carlsen (Carlsen, 2011), 


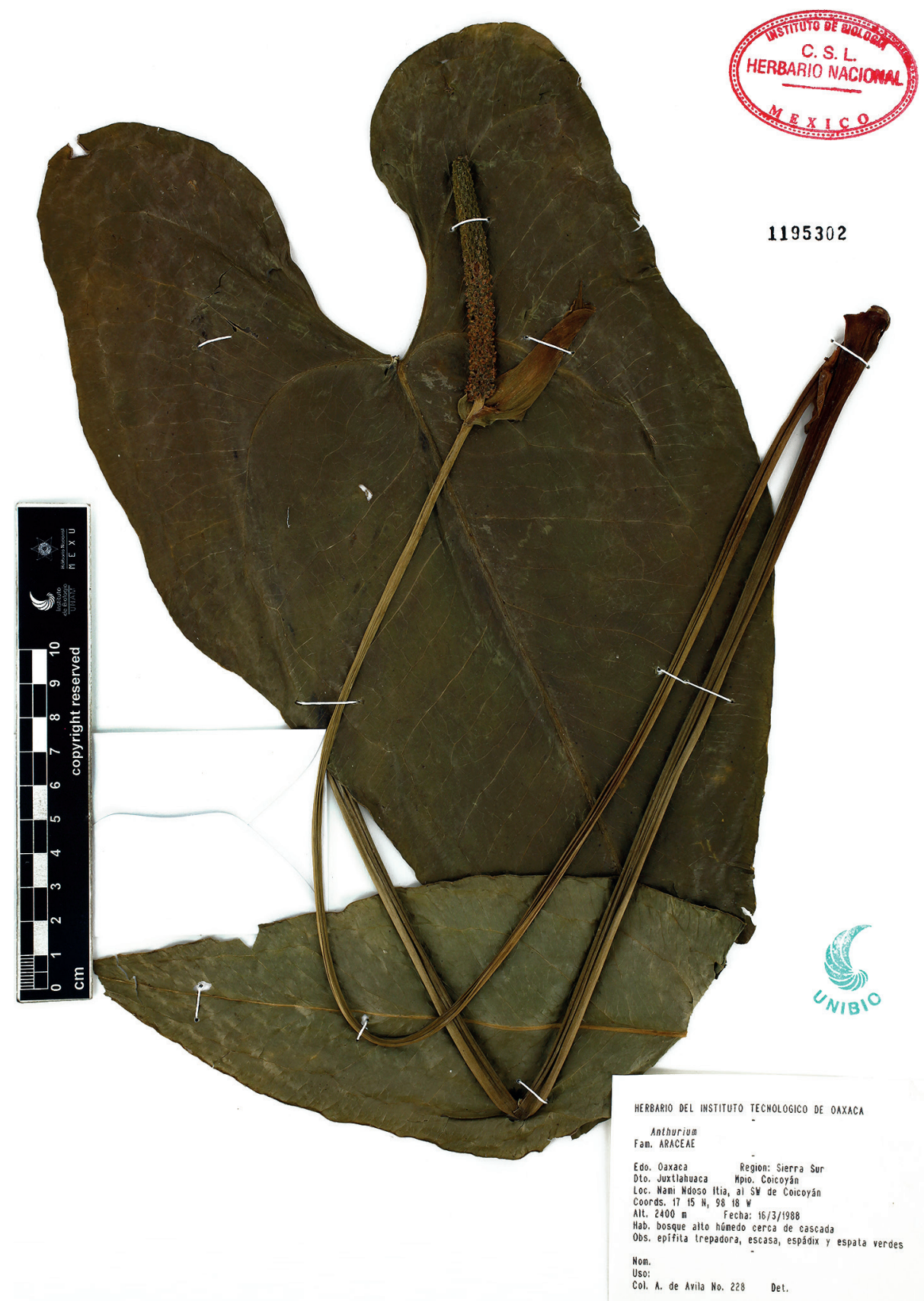

Fig. 1. Holotype of Anthurium coicoyanense Croat \& de Ávila. MEXU. 


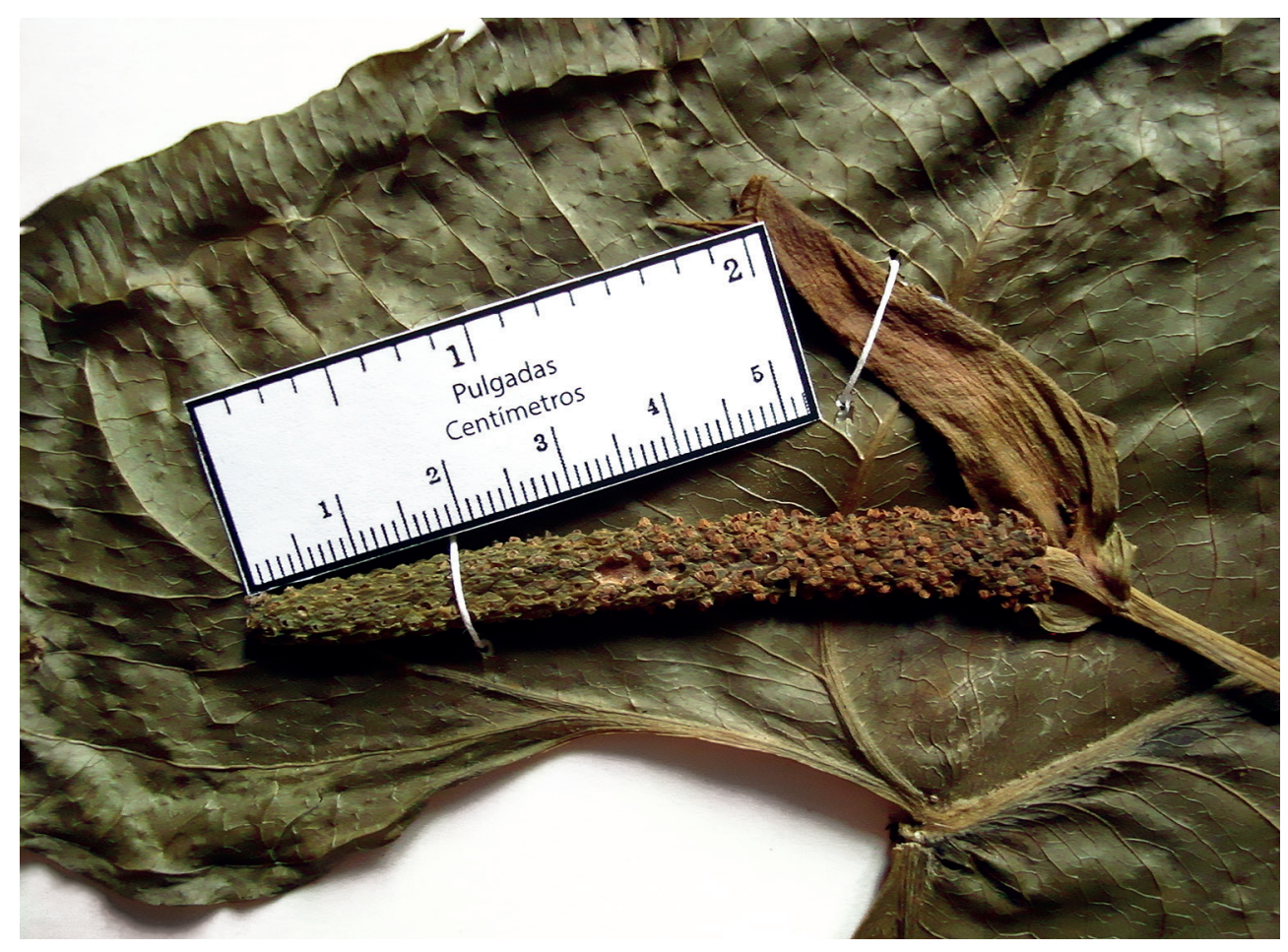

Fig. 2. Close up of the holotype, showing the inflorescence.

then a student of the senior author at the University of Missouri-St. Louis, found that at least some representatives of this group formed a distinct clade. The oldest name for this clade was proposed by H. W. Schott in his Prodromus (Schott, 1860) as grex Andiphilum, a name that will be formally resurrected to the level of section in an upcoming publication (Croat \& Carlsen, in prep.).

The new species is characterized by its hemiepiphytic habit, long-petiolate, subterete sulcate gray-green-drying petioles, narrowly ovate-triangular-sagittate narrowly acuminate blades with the anterior lobe broadly concave along the margins, a spatulate sinus, 3(4) pairs of basal veins with none of the basal veins free to the base, the $1^{\text {st }}$ pair of basal veins broadly spreading, then directed upward along the margin and regularly very remote from the margins, 10-13 pairs of primary lateral veins, and these scarcely distinct from the interprimary veins, as well as by long-pedunculate inflorescence with a green erect-spreading spathe which is shorter than the spadix, and a moderately short weakly tapered essentially sessile green 
spadix with large flowers. Anthurium coicoyanense is probably most similar to $A$. montanum Hemsl., which differs by having leaf blades proportionately much less elongated and 1.2-2 times longer than wide, with the collective veins 5-14 $\mathrm{mm}$ from the margins, as well as by having a typically purple spadix.

Anthurium coicoyanense is endemic to Mexico, known only from the type locality in Oaxaca State at $2400 \mathrm{~m}$ above sea level, in a region where the dominant vegetation is mixed pine-oak forest (bosque de pino-encino). The plant was found in a ravine near a waterfall, growing in the proximity of many species characteristic of high altitude cloud forests (bosque mesófilo de montaña) of the Pacific drainage of southern Mexico (Chamaedorea sp., Chiranthodendron pentadactylon Larreat., Cleyera integrifolia (Benth.) Choisy, Daphnopsis nevlingii J. Jiménez Ram. \& J.L. Contr., Disocactus cf. ackermannii (Haw.) Ralf Bauer, and tree ferns).

In the CATE (Creating a Taxonomic E-science) Anthurium Key (Haigh et al., 2009), the new species tracks to A. cerropelonense Matuda, differing in having blades broadly ovate with several pairs of basal veins free to the base; $A$. chamulense Matuda, differing by having a broadly, mostly arcuate sinus to broadly parabolic sinus and a frequently purple spadix; A. lucens Standl., differing in having a purplish spadix and leaf blades with dark punctations on the lower surface; and A. rzedowskii Croat differs in having more coriaceous blades with broadly concave lateral margins which are truncate to subcordate at the base.

The species is named for the type locality in the municipality of Coicoyán de las Flores in the Sierra Sur Mountains of the district of Juxtlahuaca, in the state of Oaxaca, Mexico. This description is based on the specimen held at MEXU, designated as the holotype, confirmed by the characteristics of the isotype at NY; additional collections, which had been deposited at the herbarium of the Instituto Tecnológico de Oaxaca (where the second author was employed at the time of his fieldwork), were unfortunately destroyed. It will be difficult to return to the site where this plant was found because of ongoing violence and insecurity due to the cultivation of opium poppies in the region. Other herbaria in Oaxaca (SERO and OAX) do not hold specimens from that area.

\section{ACKNOWLEDGMENTS}

We thank Dr. Abisaí García Mendoza (Jardín Botánico, Instituto de Biología, UNAM) for his kind assistance in locating the specimen we have designated as the holotype, and Dr. David Sebastian Gernandt (Herbario Nacional, Instituto de 
Biología, UNAM) for his generous authorization to publish the photographs of that specimen.

\section{LITERATURE CITED}

Carlsen, M. 2011. Understanding the origin and rapid diversification of the genus Anthurium Schott (Araceae), integrating molecular phylogenetics, morphology and fossils. Ph.D. Dissertation. Department of Biology, University of Missouri. St. Louis, USA. 157 pp.

Croat, T. B. 1983. A revision of the genus Anthurium (Araceae) of Mexico and Central America. Part 1: Mexico and Middle America. Ann. Missouri Bot. Gard. 70: 211-417.

Croat, T. B. 1991. A revision of Anthurium section Pachyneurium (Araceae). Ann. Missouri Bot. Gard. 78: 539-855.

Haigh, A., S. J. Mayo, T. Croat, L. Reynolds, M. Mora Pinto, P.C. Boyce, L. Lay, J. Bogner, B. Clark, C. Kostelac \& A. Hay. 2009. Interactive web-taxonomy for the Araceae: www.cate-araceae.org. Blumea 54: 13-15.

Pérez-Farrera, M. A. \& T. B. Croat. 2001. A new species of Anthurium (Araceae) from Chiapas, Mexico. Novon 11: 88-91.

Schott, H. W. 1860. Prodromus systematis Aroidearum. Typis Congregationis Mechitharisticae, Viena, Austria. 605 pp. 